\title{
Association of the Dopamine Transporter (SLC6A3/DAT1) Gene 9-6 Haplotype With Adult ADHD
}

\author{
B. Franke, ${ }^{1,2} *$ M. Hoogman, ${ }^{1}$ A. Arias Vasquez, ${ }^{1,2,3}$ J.G.A.M. Heister, ${ }^{2}$ P.J. Savelkoul, ${ }^{1}$ M. Naber, ${ }^{2}$ H. Scheffer, ${ }^{2}$ \\ L.A. Kiemeney, ${ }^{3}$ C.C. Kan, ${ }^{1}$ J.J.S. Kooij, ${ }^{4}$ and J.K. Buitelaar ${ }^{1}$ \\ ${ }^{1}$ Department of Psychiatry, Radboud University Nijmegen Medical Centre, Donders Institute for Brain, Cognition and Behavior, \\ Nijmegen, The Netherlands \\ ${ }^{2}$ Department of Human Genetics, Radboud University Nijmegen Medical Centre, Nijmegen, The Netherlands \\ ${ }^{3}$ Department of Epidemiology \& Biostatistics, Radboud University Nijmegen Medical Centre, Nijmegen, The Netherlands \\ ${ }^{4}$ PsyQ, Psycho-Medical Programs, The Hague, The Netherlands
}

\begin{abstract}
ADHD is a neuropsychiatric disorder characterized by chronic hyperactivity, inattention and impulsivity, which affects about 5\% of school-age children. ADHD persists into adulthood in at least $15 \%$ of cases. It is highly heritable and familial influences seem strongest for ADHD persisting into adulthood. However, most of the genetic research in ADHD has been carried out in children with the disorder. The gene that has received most attention in ADHD genetics is SLC6A3/DAT1 encoding the dopamine transporter. In the current study we attempted to replicate in adults with ADHD the reported association of a 10-6 SLC6A3-haplotype, formed by the 10-repeat allele of the variable number of tandem repeat (VNTR) polymorphism in the $3^{\prime}$ untranslated region of the gene and the 6-repeat allele of the VNTR in intron 8 of the gene, with childhood ADHD. In addition, we wished to explore the role of a recently described VNTR in intron 3 of the gene. Two hundred sixteen patients and 528 controls were included in the study. We found a 9-6 SLC6A3haplotype, rather than the 10-6 haplotype, to be associated with ADHD in adults. The intron 3 VNTR showed no association with adult ADHD. Our findings converge with earlier reports and suggest that age is an important factor to be taken into account when assessing the association of SLC6A3 with ADHD. If confirmed in other studies, the differential association of the gene with ADHD in children and in adults might imply that $S L C 6 A 3$ plays a role in modulating the ADHD phenotype, rather than causing it. () 2008 Wiley-Liss, Inc.
\end{abstract}

KEY WORDS: persistent ADHD; association study; variable number of tandem repeats (VNTR); DAT1 intron 8 VNTR; DAT1 intron 3 VNTR

Please cite this article as follows: Franke B, Hoogman M, Arias Vasquez A, Heister JGAM, Savelkoul PJ, Naber

L.A. Kiemeney, Participating as representative of the Nijmegen Biomedical Study.

*Correspondence to: B. Franke, Ph.D., Departments of Human Genetics (855) and Psychiatry, Radboud University Nijmegen Medical Centre, P.O. Box 9101, 6500 HB Nijmegen, The Netherlands. E-mail: b.franke@antrg.umcn.nl

Received 3 July 2008; Accepted 19 August 2008

DOI 10.1002/ajmg.b.30861

Published online 18 September 2008 in Wiley InterScience (www.interscience.wiley.com)
M, Scheffer H, Kiemeney LA, Kan CC, Kooij JJS, Buitelaar JK. 2008. Association of the Dopamine Transporter (SLC6A3/DAT1) Gene 9-6 Haplotype With Adult ADHD. Am J Med Genet Part B 147B:1576-1579.

\section{INTRODUCTION}

Attention deficit hyperactivity disorder (ADHD) is among the most heritable and common behavioral disorders in childhood. It affects $\sim 5 \%$ of school-age children. At least $65 \%$ of patients retain ADHD symptoms into adulthood, with at least $15 \%$ of them showing syndromal persistence [Faraone et al., 2006]. The influence of familial (possibly genetic) factors on ADHD etiology appears to be stronger in adults than in children [Faraone et al., 2000].

One of the most extensively studied genes in childhood ADHD is $S L C 6 A 3 / D A T 1$ encoding the dopamine transporter. A 40 base pair (bp) variable number of tandem repeats (VNTR) polymorphism in the $3^{\prime}$ untranslated region (UTR) of the gene has received most attention. Meta-analysis of both familybased and case-control association studies in children with ADHD has indicated overrepresentation of the 10-repeat allele of the VNTR in ADHD [Faraone et al., 2005]. More recent meta-analyses have challenged this view, and have suggested heterogeneity in the findings [Todd et al., 2005; Li et al., 2006; Yang et al., 2007].

Recent work by us and others indicates that the 10-repeat allele of the $3^{\prime}$ UTR VNTR might only increase ADHD risk in children in a haplotype with allele 6 of a VNTR in intron 8 of the gene [Brookes et al., 2006a; Asherson et al., 2007]. Both, the $3^{\prime}$ UTR VNTR and the intron 8 VNTR have been suggested to influence the expression of SLC6A3. However, there is inconsistency in the findings of in vitro and in vivo studies investigating allele-specific expression [Spencer et al., 2005; Brookes et al., 2007]. This may suggest that neither VNTR is functional by itself, but (incompletely) tags an unknown functional site. It is likely that the haplotype of both VNTRs improves tagging of this functional variant.

A first study of the two SLC6A3 VNTRs in adults with ADHD, though of limited samples size, could not confirm the association of the 10-6 haplotype with the persistent form of the disorder [Bruggemann et al., 2007]. In the current study we, again, attempted to replicate the haplotype association findings from childhood ADHD in a second sample of adult ADHD patients and also explored the role of a recently described additional VNTR in intron 3 of SLC6A3 [Mijyajima et al., 2006].

\section{MATERIALS AND METHODS}

Participants

Patients $(n=216)$ had been referred for assessment of ADHD to the outpatient clinic of GGZ Delfland in Delft, to 
Parnassia, psycho-medical centre in The Hague, or to the department of Psychiatry at the Radboud University Nijmegen Medical Centre in Nijmegen, The Netherlands. Subjects were included if a clinical diagnosis of adult ADHD with childhood onset was established. Part of the patients has been described before [Bekker et al., 2005; Kooij et al., 2005].

Controls $(n=528)$ were obtained from the Nijmegen Biomedical Study (NBS, www.nijmegenbiomedischestudie.nl), a population-based survey conducted by the Departments of Epidemiology \& Biostatistics and of Clinical Chemistry of the Radboud University Nijmegen Medical Centre [Hoogendoorn et al., 2006]. The control group was frequency-matched for gender with the patient group.

Patients and controls were of Caucasian ethnic background. The study was approved by regional medical ethics committees. All participants completed written informed consent.

\section{Diagnostic Assessments}

Prior to inclusion, all patients underwent a standard clinical assessment consisting of a psychiatric evaluation by experienced psychiatrists using a semi-structured diagnostic interview for ADHD and comorbid disorders, the Dutch version of structured diagnostic interviews for retrospective diagnosis of childhood onset ADHD and current symptoms. For current ADHD symptoms during the last 6 months, also a Dutch version of the DSM-IV ADHD Rating Scale, based on the 18 DSM-IV items for ADHD, was used [DuPaul et al., 1998; Kooij et al., 2005]. The ADHD Rating Scale has been used in epidemiologic and clinical research in adults in the United States and in The Netherlands [Murphy and Barkley, 1996; Kooij et al., 2005]. To be given a full diagnosis of adult ADHD, subjects had to (A) meet at least 6 out of 9 DSM-IV criteria of inattention and/or hyperactivity/impulsivity for a diagnosis of ADHD in childhood and at least 5 out of 9 criteria in adulthood, (B) describe a chronic persisting course of ADHD symptoms from childhood to adulthood, and (C) endorse a moderate to severe level of impairment attributed to the ADHD symptoms. A cut-off point of 5 of 9 criteria was set for adult diagnosis of ADHD based on literature and epidemiological data using the same DSM-IV ADHD Rating Scale [Kooij et al., 2005]. In order to obtain information about lifetime ADHD symptoms and impairment, the patient, the partner and, if available, the parents were interviewed. Information on school reports was examined in order to sustain the diagnosis in childhood. Diagnostic criteria have been described in more detail elsewhere [Bekker et al., 2005; Kooij et al., 2005]. Table I shows the demographics of the patient sample. Controls were also screened for presence of current ADHD symptoms using the DSM-IV ADHD Rating Scale [Kooij et al., 2005] and were excluded if 4 or more symptoms were present.

\section{Genotyping and Statistical Analysis}

Genotyping of the VNTRs in the $3^{\prime}$ UTR and intron 8 has been described earlier [Brookes et al., 2006b; Boonstra et al., 2008]. The 63 base pair (bp) VNTR in intron 3 of the gene was genotyped using a PCR-based method on $62.5 \mathrm{ng}$ genomic DNA using $0.4 \mu \mathrm{M}$ of forward (5'-GAAGTTGGCTGGTTGGTGAG$\left.3^{\prime}\right)$ and reverse primer (5'-ACCAGAGTCCCCCTTACCAA- $\left.3^{\prime}\right)$, respectively, $0.25 \mathrm{mM}$ dNTPs and $0.5 \mathrm{U}$ Taq DNA polymerase (Invitrogen, Breda, The Netherlands) in a buffer containing $60 \mathrm{mM}$ Tris- $\mathrm{HCl} \mathrm{pH} 9.5,15 \mathrm{mM} \mathrm{NH}_{2} \mathrm{SO}_{4}$ and $2 \mathrm{mM} \mathrm{MgCl}_{2}$. The cycling conditions for amplification involved $5 \mathrm{~min}$ at $92^{\circ} \mathrm{C}$, followed by 35 cycles of $1 \mathrm{~min} 92^{\circ} \mathrm{C}, 1 \mathrm{~min}$ at $61^{\circ} \mathrm{C}$ and $1 \mathrm{~min}$ $72^{\circ} \mathrm{C}$ and an extra $10 \mathrm{~min}$ at $72^{\circ} \mathrm{C}$. Analysis on a $2 \%$ agarose gel yielded distinct bands at 596 and $659 \mathrm{bp}$ for the most common
TABLE I. Patient Characteristics

\begin{tabular}{|c|c|c|}
\hline Characteristics & $\mathrm{n}$ & Percentage \\
\hline Number of subjects & 216 & \\
\hline Age (mean and range) & 36.0 & $18-62$ \\
\hline Males & 105 & 48.6 \\
\hline \multicolumn{3}{|l|}{ Marital status } \\
\hline Married/relationship & 129 & 59.7 \\
\hline Single/divorced/living with parents & 84 & 38.9 \\
\hline Unknown & 3 & 1.4 \\
\hline \multicolumn{3}{|l|}{ Educational level } \\
\hline Lower educational level & 56 & 25.9 \\
\hline High school & 141 & 65.3 \\
\hline University & 15 & 6.9 \\
\hline Unknown & 4 & 1.9 \\
\hline \multicolumn{3}{|l|}{ DSM IV axis I disorder } \\
\hline ADHD combined type & 187 & 86.6 \\
\hline ADHD hyperactive/impulsive type & 8 & 3.7 \\
\hline ADHD inattentive type & 21 & 9.7 \\
\hline Any comorbid axis I disorder ${ }^{a}$ & 177 & 81.9 \\
\hline Multiple $(\geq 2)$ comorbid axis I disorders ${ }^{a}$ & 91 & 42.1 \\
\hline Any mood disorder ${ }^{\mathrm{a}}$ & 129 & 59.7 \\
\hline Any anxiety disorder ${ }^{\mathrm{a}}$ & 74 & 34.3 \\
\hline Any substance use disorder ${ }^{a}$ & 49 & 22.7 \\
\hline Bulimia Nervosa $^{a}$ & 9 & 4.2 \\
\hline $\begin{array}{l}\text { Co-morbid Borderline Personality } \\
\text { Disorder }^{\mathrm{b}}\end{array}$ & 35 & 17.9 \\
\hline
\end{tabular}

${ }^{\text {a Past or present. }}$

${ }^{\mathrm{b}}$ Data available for 206 subjects.

alleles 7 and 8. Generally, all three genotyping assays have been validated earlier and 5\% duplicates and blanks were taken along as quality controls during genotyping. HardyWeinberg equilibrium (HWE) was assessed for all genotypes in all available samples using a $\chi^{2}$ statistic. Only the most common alleles/genotypes were taken into account in the haplotype analysis and the tests of association with ADHD. Genotype frequencies of the SLC6A3 polymorphisms were compared between cases and controls using a $\chi^{2}$ test. Odds ratios (ORs) and $95 \%$ confidence intervals (CIs) were estimated using SPSS (version 14.0). SLC6A3 haplotypes of the $3^{\prime}$ UTR and intron 8 (and intron 3) VNTRs with ADHD were estimated using the haplo.em function implemented in the haplo.stats package [Schaid et al., 2002], which computes maximum likelihood estimates of haplotype probabilities, together with posterior probabilities of haplotype pairs for each subject. Haplotype association analyses were done using the haplo.score function implemented in haplo.stats. Briefly, this package computes score statistics to test associations between haplotypes and a trait, and allows adjustment for other determinants. This analysis was corrected for multiple testing by applying the simulate $=$ TRUE parameter in haplo.score which gives simulated $p$ values. These simulated haplotype score statistics are calculated from a permuted re-ordering of the trait (ADHD status) and SLC6A3 polymorphisms. We used 1,000 permutations for all the analyses.

\section{RESULTS}

Genotype distributions of all three polymorphisms were in Hardy-Weinberg equilibrium $(P>0.05)$. The overall haplotype distributions were significantly different in cases and controls. We found global evidence for association of SLC6A3 with adult $\mathrm{ADHD}$ (haplo.score global $P=0.01$ ). This difference was not explained by the 10-6 haplotype, but rather by the $9-6$ haplotype which was significantly more frequent in cases than in controls (haplotype-specific $P=0.001$ ) (Table II). Inclusion 
TABLE II. Genotype Analysis of the $3^{\prime}$ UTR and Intron 8 and 3 VNTRs of the SLC6A3 Gene and Haplotype Analysis for the $3^{\prime}$ UTR and Intron 8 VNTRs

\begin{tabular}{|c|c|c|c|c|c|}
\hline \multirow[b]{2}{*}{ Genotypes } & \multicolumn{2}{|c|}{ Frequency (\%) } & \multirow[b]{2}{*}{ Pearson $\chi^{2} P$-value } & \multirow[b]{2}{*}{ OR } & \multirow[b]{2}{*}{$95 \% \mathrm{CI}$} \\
\hline & Controls & Cases & & & \\
\hline \multicolumn{6}{|l|}{$3^{\prime}$ UTR } \\
\hline $10 / 10$ & $294(58.0)$ & $108(50.7)$ & 0.085 & 1 & \\
\hline $10 / 9$ & $191(37.7)$ & 89 (41.8) & & 1.27 & $0.91-1.8$ \\
\hline $9 / 9$ & $22(4.3)$ & $16(7.5)$ & & 1.98 & $1.00-3.91$ \\
\hline \multicolumn{6}{|l|}{ Intron 8} \\
\hline $6 / 6$ & $306(60.4)$ & $128(62.7)$ & 0.731 & 1 & \\
\hline $6 / 5$ & $178(35.1)$ & $69(33.8)$ & & 0.93 & $0.66-1.31$ \\
\hline $5 / 5$ & $23(4.5)$ & $7(3.4)$ & & 0.73 & $0.30-1.74$ \\
\hline \multicolumn{6}{|l|}{ Intron 3} \\
\hline $7 / 7$ & 336 (63.9) & $139(65.0)$ & 0.809 & 1 & \\
\hline $7 / 8$ & $176(33.5)$ & $71(33.2)$ & & 0.975 & $0.695-1.369$ \\
\hline $8 / 8$ & $14(2.7)$ & $4(1.9)$ & & 0.691 & $0.224-2.135$ \\
\hline \multirow[t]{2}{*}{ Haplotypes* } & \multicolumn{2}{|c|}{ Frequency (\%) } & Score test $P$-value & OR & $95 \% \mathrm{CI}$ \\
\hline & Controls & Cases & & & \\
\hline $10-6$ & 70.0 & 66.2 & & 1 & \\
\hline $9-5$ & 16.5 & 16.3 & 0.99138 & 1.06 & $0.77-1.46$ \\
\hline $9-6$ & 6.4 & 11.7 & 0.00106 & 2.05 & $1.35-3.1$ \\
\hline $10-5$ & 4.6 & 3.2 & 0.18033 & 0.74 & $0.39-1.42$ \\
\hline
\end{tabular}

Four haplotypes were found at frequencies above $1 \%$, representing $97.4 \%$ of all haplotypes in the sample.

*Haplo.score global $P=0.01$.

of the intron 3 VNTR did not change the results (data not shown).

\section{DISCUSSION}

Although the $S L C 6 A 3 / D A T 1$ gene is the best-studied gene in childhood ADHD, only few studies have looked at this gene in adult ADHD genetics research. Only one earlier study has tried to replicate the 10-6 haplotype association with childhood ADHD in adult patients. This study, in 122 adult patients and 174 controls, did not find association with SLC6A3, neither with the 10-6 haplotype, nor with any other haplotype formed by the $40 \mathrm{bp}$ VNTR polymorphism in the $3^{\prime}$ untranslated region of the gene and the $30 \mathrm{bp}$ VNTR in intron 8 [Bruggemann et al., 2007]. Using a larger sample, our data also suggest a lack of association with $10-6$, but we find the adult disorder to be associated with the 9-6 haplotype in SLC6A3. Our findings converge with recent data of the $3^{\prime}$ UTR VNTR from a prospective 13-year follow-up study in 147 young adults with $\mathrm{ADHD}$ and 73 controls, indicating that more ADHD symptoms and externalizing behaviors were present in the 9/10 than in the 10/10 genotype for the group as a whole [Barkley et al., 2006]. Interestingly, the effects of the genotype became more pronounced with increasing age of the participants. More individuals with a DSM diagnosis of ADHD in adulthood were also found among those having the $9 / 10$ genotype (53\%) than among the 10/10 homozygous group (35\%) [Barkley et al., 2006]. Our own neuropsychological studies in a subset of 45 adults with ADHD from the current study also support the current findings in that the heterozygous 10-allele carriers (mostly 9/10) were shown to have slower inhibition during the Change task [Boonstra et al., 2008]. Similar results were recently reported in 75 young healthy adults [Caldu et al., 2007].

Rather than age being the factor modifying the association of SLC6A3 with ADHD, geographical origin might form an alternative explanation for the results of the current study. However, we do not think that this is the cause of our findings, given our recent findings within the IMAGE study, in which we were able to confirm the association of the 10-6 haplotype with childhood ADHD [Asherson et al., 2007]. This sample contains more than 300 families from The Netherlands, who also show the expected overtransmission of the 10-6 haplotype to affected offspring, when analyzed separately from all other samples (unpublished results).

Of course, our findings of the SLC6A3 9-6 haplotype association with adult ADHD are in need of replication, before we can judge if the association is really true. Actually, although $S L C 6 A 3$ has been the subject of numerous studies in children, the evidence for the involvement of the gene in ADHD is still rather slim. Meta-analyses of the $3^{\prime}$ UTR VNTR have suggested association of either of the two common alleles (10-repeat and 9-repeat) or neither allele with the disorder and related phenotypes [Faraone et al., 2005; Todd et al., 2005; Li et al., 2006; Yang et al., 2007]. Even in those meta-analyses that did show association with ADHD, the significance of the findings was limited and far from reaching genome-wide levels of significance, though large numbers of patients were included. Clinical heterogeneity and environmental factors-but also age-might be important factors to take into account when assessing the association of $S L C 6 A 3$ with ADHD.

In conclusion, if confirmed in other studies, our data bear the intriguing suggestion that the $S L C 6 A 3$ haplotype associated with ADHD in adults is different from the one associated with the childhood disorder. Since dopamine transporter density decreases during life [Spencer et al., 2005] and ADHD symptoms are known to change during adolescence [Biederman et al., 2000], the differential association of $S L C 6 A 3$ with ADHD might reflect changing requirements on the dopaminergic system during life. Furthermore, regulation of the dopamine transporter is influenced by environmental factors like smoking, ethanol and several drugs [Madras et al., 2005], that are used more often by adults than by children. A differential association of the $S L C 6 A 3$ gene with ADHD in children and in adults might imply that the gene plays a role in modulating the ADHD phenotype, rather than causing it. 


\section{ACKNOWLEDGMENTS}

We thank all patients and controls participating in the study. We thank Marije Boonstra for her role in patient phenotyping and Remco Makkinje for help in genotyping. Controls were derived from the Nijmegen Biomedical Study. Principal investigators of the Nijmegen Biomedical Study are L.A.L.M. Kiemeney, M. den Heijer, A.L.M. Verbeek, D.W. Swinkels and B. Franke. This project was partly funded by the Hersenstichting Nederland.

\section{REFERENCES}

Asherson P, Brookes K, Franke B, Chen W, Gill M, Ebstein RP, Buitelaar J, Banaschewski T, Sonuga-Barke E, Eisenberg J, Manor I, Miranda A, Oades RD, Roeyers H, Rothenberger A, Sergeant J, Steinhausen HC, Faraone SV. 2007. Confirmation that a specific haplotype of the dopamine transporter gene is associated with combined-type ADHD. Am J Psychiatry 164:674-677.

Barkley RA, Smith KM, Fischer M, Navia B. 2006. An examination of the behavioral and neuropsychological correlates of three ADHD candidate gene polymorphisms (DRD4 7+, DBH TaqI A2, and DAT1 40 bp VNTR) in hyperactive and normal children followed to adulthood. Am J Med Genet Part B 141B:487-498.

Bekker EM, Overtoom CC, Kooij JJ, Buitelaar JK, Verbaten MN, Kenemans JL. 2005. Disentangling deficits in adults with attention-deficit/hyperactivity disorder. Arch Gen Psychiatry 62:1129-1136.

Biederman J, Mick E, Faraone SV. 2000. Age-dependent decline of symptoms of attention deficit hyperactivity disorder: Impact of remission definition and symptom type. Am J Psychiatry 157:816-818.

Boonstra AM, Kooij JJ, Buitelaar JK, Oosterlaan J, Sergeant JA, Heister JG, Franke B. 2008. An exploratory study of the relationship between four candidate genes and neurocognitive performance in adult ADHD. Am J Med Genet Part B 147B:397-402.

Brookes KJ, Mill J, Guindalini C, Curran S, Xu X, Knight J, Chen CK, Huang YS, Sethna V, Taylor E, Chen W, Breen G, Asherson P. 2006a. A common haplotype of the dopamine transporter gene associated with attentiondeficit/hyperactivity disorder and interacting with maternal use of alcohol during pregnancy. Arch Gen Psychiatry 63:74-81.

Brookes K, Xu X, Chen W, Zhou K, Neale B, Lowe N, Anney R, Franke B, Gill M, Ebstein R, Buitelaar J, Sham P, Campbell D, Knight J, Andreou P, Altink M, Arnold R, Boer F, Buschgens C, Butler L, Christiansen H, Feldman L, Fleischman K, Fliers E, Howe-Forbes R, Goldfarb A, Heise A, Gabriels I, Korn-Lubetzki I, Johansson L, Marco R, Medad S, Minderaa R, Mulas F, Muller U, Mulligan A, Rabin K, Rommelse N, Sethna V, Sorohan J, Uebel H, Psychogiou L, Weeks A, Barrett R, Craig I, Banaschewski T, Sonuga-Barke E, Eisenberg J, Kuntsi J, Manor I, McGuffin P, Miranda A, Oades RD, Plomin R, Roeyers H, Rothenberger A, Sergeant J, Steinhausen HC, Taylor E, Thompson M, Faraone SV, Asherson P. 2006b. The analysis of 51 genes in DSM-IV combined type attention deficit hyperactivity disorder: Association signals in DRD4, DAT1 and 16 other genes. Mol Psychiatry 11:934-953.

Brookes KJ, Neale BM, Sugden K, Khan N, Asherson P, D’Souza UM. 2007. Relationship between VNTR polymorphisms of the human dopamine transporter gene and expression in post-mortem midbrain tissue. Am J Med Genet Part B 144B:1070-1078.

Bruggemann D, Sobanski E, Alm B, Schubert T, Schmalzried H, Philipsen A, Breen G, Becker T, Georgi A, Skowronek MH, Schulze TG, Treutlein J,
Rietschel M. 2007. No association between a common haplotype of the 6 and 10-repeat alleles in intron 8 and the $3^{\prime}$ UTR of the DAT1 gene and adult attention deficit hyperactivity disorder. Psychiatr Genet 17:121.

Caldu X, Vendrell P, Bartres-Faz D, Clemente I, Bargallo N, Jurado MA Serra-Grabulosa JM, Junque C. 2007. Impact of the COMT Val108/158 Met and DAT genotypes on prefrontal function in healthy subjects. Neuroimage 37:1437-1444.

DuPaul GJ, Power TJ, Anastopoulos AD, Reid R. 1998. ADHD rating scaleVI. Checklists, norms and clinical interpretation. New York: The Guilford Press.

Faraone SV, Biederman J, Monuteaux MC. 2000. Toward guidelines for pedigree selection in genetic studies of attention deficit hyperactivity disorder. Genet Epidemiol 18:1-16.

Faraone SV, Perlis RH, Doyle AE, Smoller JW, Goralnick JJ, Holmgren MA, Sklar P. 2005. Molecular genetics of attention-deficit/hyperactivity disorder. Biol Psychiatry 57:1313-1323.

Faraone SV, Biederman J, Mick E. 2006. The age-dependent decline of attention deficit hyperactivity disorder: A meta-analysis of follow-up studies. Psychol Med 36:159-165.

Hoogendoorn EH, Hermus AR, de VF, Ross HA, Verbeek AL, Kiemeney LA, Swinkels DW, Sweep FC, den Heijer M. 2006. Thyroid function and prevalence of anti-thyroperoxidase antibodies in a population with borderline sufficient iodine intake: Influences of age and sex. Clin Chem 52:104-111.

Kooij JJ, Buitelaar JK, van den Oord EJ, Furer JW, Rijnders CA, Hodiamont PP. 2005. Internal and external validity of attention-deficit hyperactivity disorder in a population-based sample of adults. Psychol Med 35:817-827.

Li D, Sham PC, Owen MJ, He L. 2006. Meta-analysis shows significant association between dopamine system genes and attention deficit hyperactivity disorder (ADHD). Hum Mol Genet 15:2276-2284.

Madras BK, Miller GM, Fischman AJ. 2005. The dopamine transporter and attention-deficit/hyperactivity disorder. Biol Psychiatry 57:1397-1409.

Mijyajima F, Haddley K, Bubb J, Deakin W, Pendleton N, Horan M, Ollier W, Payton A, Quinn J. 2006. Functionality and association study of a novel variable number of tandem repeat (VNTR) polymorphism of dopamine transporter (SLC6A3) with general cognitive abilities. Am J Med Genet Part B 141B(7): (meeting abstract).

Murphy K, Barkley RA. 1996. Attention deficit hyperactivity disorder adults: Comorbidities and adaptive impairments. Compr Psychiatry 37:393-401.

Schaid DJ, Rowland CM, Tines DE, Jacobson RM, Poland GA. 2002. Score tests for association between traits and haplotypes when linkage phase is ambiguous. Am J Hum Genet 70:425-434.

Spencer TJ, Biederman J, Madras BK, Faraone SV, Dougherty DD, Bonab AA, Fischman AJ. 2005. In vivo neuroreceptor imaging in attentiondeficit/hyperactivity disorder: A focus on the dopamine transporter. Biol Psychiatry 57:1293-1300.

Todd RD, Huang H, Smalley SL, Nelson SF, Willcutt EG, Pennington BF, Smith SD, Faraone SV, Neuman RJ. 2005. Collaborative analysis of DRD4 and DAT genotypes in population-defined ADHD subtypes. J Child Psychol Psychiatry 46:1067-1073.

Yang B, Chan RC, Jing J, Li T, Sham P, Chen RY. 2007. A meta-analysis of association studies between the 10-repeat allele of a VNTR polymorphism in the $3^{\prime}$-UTR of dopamine transporter gene and attention deficit hyperactivity disorder. Am J Med Genet Part B 144B:541550 . 